\title{
The Faith in Humanity and International Criminal Law
}

\section{Tallgren, Immi}

Oxford University Press

2017-08-01

Tallgren , I 2017 , The Faith in Humanity and International Criminal Law . in M Garcia-Salmones Rovira, M Koskenniemi \& P Amorosa (eds), International Law and Religion : Historical and Contemporary Perspectives . Oxford University Press, Oxford . https://doi.org/10.1093/oso/

http://hdl.handle.net/10138/326857

https://doi.org/10.1093/oso/9780198805878.003.0015

unspecified

publishedVersion

Downloaded from Helda, University of Helsinki institutional repository.

This is an electronic reprint of the original article.

This reprint may differ from the original in pagination and typographic detail.

Please cite the original version. 


\title{
14
}

\section{The Faith in Humanity and International Criminal Law}

\author{
Immi Tallgren ${ }^{1}$
}

\section{Introduction}

'There is an idea that we absolutely have to get used to ... humanity is left on this earth to its own devices and can only count on itself to direct its own destiny', ${ }^{2}$ urged Emile Durkheim a century ago. Nevertheless, there is a cosmic loneliness in the idea of 'humanity' all on its own charged with directing its destiny, against all odds and hazards. The efforts to find guidance and create some stable structure in the declared absence of divinities take many forms. Fears for the survival and health of human societies and the human species may be local, but the responses today are often presented as beyond the national, be it regional, international, or global. Internationalism and humanitarianism, international law and institutions, and the human rights ideology are, for many, contributing to preventing and alleviating disasters, threats, and fears, carrying a universal promise of protection of humans and 'humanity'. ${ }^{3}$

My chapter participates in this research project by reflecting on the potential transformation of international law into a new kind of religiousness, 'internationalism operating on the basis of faith that has often left itself unarticulated as such' but has 'made sacred the laws of nations and the task of the judges'. ${ }^{4}$ In academic commentary today, it is not uncommon to address international law in terms of

${ }^{1}$ I would like to thank warmly the conveners of the research project 'International Law and Religion' at the Erik Castrén Institute and the editors of the volume, as well as all friends and colleagues who have commented on the draft in its various forms. I am grateful for the research funding Emil Aaltonen Foundation provided during the early phase of this research.

2 Emile Durkheim, contribution to discussion in F. Abauzit et al., 'Les Sentiments religieux à l'heure actuelle' (Paris: Vrin, 1919), translated and reprinted in J. Redding and W. S. F. Pickering, eds., Durkheim on Religion (London; Boston: Routledge and Kegan Paul, 1975), p. 187.

3 See, for example, Ruti G. Teitel, Humanity's Law (Oxford: Oxford University Press, 2011), see preface and pp. 3-4; Antônio Augusto Cançado Trindade, International Law for Humankind: Towards a New Jus Gentium (The Netherlands: Martinus Nijhoff Publishers, 2010). On representations of human suffering as a key to these dynamics, see, for example, Richard Ashby Wilson and Richard D. Brown, eds, Humanitarianism and Suffering (New York: Cambridge University Press, 2009).

${ }^{4}$ The research statement of the Working Group on International Law and Religion. 
religiousness, attributing to it religion-like roles or calling its adherents believers or priests. ${ }^{5}$ Much of the attention has focused on human rights, a belief in which is considered at least as 'a kind of world-wide secular religion'. ${ }^{6}$ I have myself referred to 'belief' and 'religiousness' in discussing international criminal law and its institutional practice by the International Criminal Court (ICC) and the ad hoc international criminal tribunals, as well as the ways in which they are represented in (international) political fora, civil society, academia, and media. ${ }^{7}$ In those fora, international criminal law and its institutional practice at times appear to call for a faith in law, as a token for the collective desires of 'humanity's' progress towards a better future when faced with violence and 'evil' that is addressed as international criminality. For those having the faith, the law and its institutional practice manifest consensual moral boundaries, those boundaries being translated into universally applicable policies supposedly beneficial for all human beings, thereby building a moral community of 'humanity', if not immediately then at least in the future. The faith in 'humanity' and its law is—or some residual components of it—celebrated in a cult of criminal justice with its distinct rituals, symbols, and mythologies. ${ }^{8}$

This chapter takes issue with the transcendental reference in 'humanity' by situating it within the broader discussions on religion, the non-deist religions in particular. ${ }^{9}$ In the search for further continuities and breaks, I propose here to put today's

${ }^{5}$ For a discussion on this, see, for example, David Kennedy, 'Losing Faith in the Secular: Law, Religion, and the Culture of International Governance', in Religion and International Law, edited by Mark Janis and Carolyn Evans (The Hague; Boston: Martinus Nijhoff Publishers, 1999), pp. 309-20. In a historical perspective, Nathaniel Berman, " "The Sacred Conspiracy”: Religion, Nationalism, and the Crisis of Internationalism', Leiden Journal of International Law 25, no. 1 (2012): pp. 9-54; John Haskell, 'Divine Immanence: The Evangelical Foundations of Modern Anglo-American Approaches to International Law', Chinese Journal of International Law 11, no. 3 (2012): pp. 429-67.

${ }^{6}$ Elie Wiesel, 'A Tribute to Human Rights', in The Universal Declaration of Human Rights: Fifty Years and Beyond, edited by Danieli Yael et al. (Amityville, N.Y.: Baywood, 2009), p. 3. For a virulent critique of Wiesel, see Michael Ignatieff, Human Rights as Politics and Idolatry (Princeton: Princeton University Press, 2003). See also, for example, Elizabeth M. Bucar and Barbra Barnett, eds, Does Human Rights Need God? (Grand Rapids, Mich.: W. B. Eerdmans, 2005); Helle Porsdam, ed., Civil Religion, Human Rights and International Relations (Cheltenham: Edward Elgar, 2012). Susan Marks evokes 'a contemporary cliché' on human rights as 'a secular religion: an object of faith, a basis for hope and a code of morality we can all accept, whatever other systems of belief we may cherish or reject'. 'Human Rights in Disastrous Times', in The Cambridge Companion to International Law, edited by James Crawford and Martti Koskenniemi (Cambridge: Cambridge University Press, 2012), pp. 309$26,313-14$.

7 See, for example, Immi Tallgren, 'The Sensibility and Sense of International Criminal Law', European Journal of International Law 13, no. 3 (2002): pp. 561-95.

8 For discussion, see, for example, Edwin Bikundo, International Criminal Law: Using or Abusing Legality? (Farnham: Ashgate, 2014), in particular pp. 15-45; Kamari M. Clarke, Fictions of Justice (Cambridge; New York: Cambridge University Press, 2009). See also Audra Mitchell, International Intervention in a Secular Age: Re-enchanting Humanity? (London: Routledge, 2014).

9 I will not focus on the pair of words 'civil religion' that has either a fairly recent, primarily North American context of understanding following Robert Bellah's much-discussed article of 1967, or figures in eighteenth- and nineteenth-century European thought, associated primarily to Jean-Jacques Rousseau or John Stuart Mill. See Robert Bellah, 'Civil Religion in America', Journal of the American Academy of Arts and Sciences 96, no. 1 (Winter, 1967): pp. 1-21; Jean-Jacques Rousseau, Du contrat social (Paris: Garnier-Flammarion, 1966 [1762]); John Stuart Mill, 'The Utility of Religion', in Three Essays on Religion (Amherst: Prometheus, 1998 [1874]). 
discussions on religiousness of international law in front of an alternative mirror in the work of three French thinkers: Henri Saint-Simon (1760-1825), Auguste Comte (1798-1857) and Emile Durkheim (1858-1917). In their distinct historical and intellectual landscapes, they also believed that the intertwined evolution of 'new' moral rules and internationalism were to accompany and guide a general economical, political, and social progress of the human communities or 'humanity' towards greater happiness, both individually and collectively. The period from Saint-Simon's first publication in 1802 to Durkheim's death in 1917, encompassing in between them Comte's prolific career, is a major part of international law's 'rise'. ${ }^{10}$ The period could be characterized by the contradictory aftermath of the French revolution in the turmoil of reforms and conservatism, the increasing role of science and technology and the decreasing role of religion; industrialization and its social effects; the emergence of utilitarianism; romanticism and the birth of historiography, and many other features. ${ }^{11}$ Saint-Simon, Comte and Durkheim could all, in broad terms, be described as enthusiastic towards the advances of science, technology, economy, and commerce, and the related changes in societies. However, they also shared a fundamental anxiety: should utilitarian logics become exclusive in the absence of religions, any apparent progress could end up being used for negative ends. The unity of societies was at risk. A dissolution of 'humanity' in the egoist materialism constituted 'la grande hérésie' haunting the modern world, to quote Comte. ${ }^{12}$ The key question for the three thinkers was: in the conditions of industrialism and division of labour, what binds societies together, to replace the role earlier held by religion? Whereas they celebrated some aspects of individualism and democratic government, they also saw dangers in them, here in the words of Durkheim: 'Political liberty is a means, not an end.... If those who handle this weapon do not know how to use it in fruitful battles, they will not be slow in turning it against themselves. ${ }^{13}$

To counter such scenarios, they emphasized how spiritual, religious, and moral dimensions consisting of commonly held beliefs transmitted from generation to generation remain essential for the health of societies. All three were interested in what these commonly held beliefs are or should be, and each developed ideas of secular religiousness. Their focus was thus not on the French ideas of their times

10 For this period of time in the history of international law, see, Martti Koskenniemi, The Gentle Civilizer of Nations: The Rise and Fall of International Law 1870-1960 (Cambridge: Cambridge University Press, 2002), pp. 266-352. See also Wilhelm G. Grewe, The Epochs of International Law (Berlin; New York: Walter de Gruyter, 2000), pp. 422-4, 438-542.

11 For a poetic description of the nineteenth century, see, for example, Juliette Grange, La philosophie d'Auguste Comte: science, politique, religion (Paris: PUF, 1996), pp. 5-7.

12 Auguste Comte, Système de politique positive ou traité de sociologie instituant la religion de l'Humanité, I (Paris: Libraire positiviste, Georges Crès et Cie, 1851-54), p. 641. Similar anxieties were expressed earlier by Rousseau, followed by Tocqueville and Mill, see Ronald Beiner, Civil Religion (New York: Cambridge University Press, 2011), pp. 261-2.

13 Emile Durkheim, 'L'Individualisme et les intellectuels', in Revue Bleue 4e série, X, (1898): pp. 7-13, 10; translated by S. and J. Lukes, Political Studies, XVII (1969), pp. 19-30, reprinted in W. S. F. Pickering, Durkheim on Religion (London and Boston: Routledge \& K. Paul, 1975), pp. 59-73, at p. 70 . 
in the sense of strict separation of the religious and the political, but rather on the design of a secular civil religion that mobilizes the affects and beliefs for the benefit of society and of 'humanity'. My reading of Saint-Simon, Comte, and Durkheim highlights themes or elements that were common and central to all of them: The progress of humans and their communities occurs both by natural or 'biological' (Comte) evolution of human capacities, competencies and their communities, and by increasing cooperation, individually and collectively. Solidarity, sociability, or social sentiment are evoked often and forcefully. The three thinkers speak in general, universalizing terms, be it of humanity or the individual. They tend to attribute human beings with a natural instinct of sociability, sharing, and caring. They focus on the protection of individuals, human communities, and human life in general, faced with continuous existential dangers. The renouncement of war as a means of politics, and the desuetude of militarism as a way to organize societies or international relations is an important part of that. In Comte's work particularly, this protection and pacification also take the form of concern for the cultural and historical achievements and monuments of humanity and the call for common limits and precaution in exploiting the Earth's resources. Saint-Simon and Comte, in particular, share the conviction that international (primarily figured as European) cooperation and integration is both beneficial and unavoidable. International institutions and rules are seen as a way of achieving the goals uniting human beings and nations as they follow their instincts of sociability and solidarity. Simultaneously, they act as a safeguard against the destructive potential present in humans themselves. In this exercise, an avant-garde role is given to European industrial states; a certain type of society and economic organization becomes the model and measuring unit of common human progress.

Presented in these broad lines, the parallels of their ideas with today's internationalism and the objectives of international law strike one as obvious, both in the scope of ambitions and in the limitations of their realization. ${ }^{14}$ Yet their work is clearly just a tiny and random path amongst many others. What to make out of such comparisons and what methodological temptations or concerns are at stake? As Samuel Moyn puts it, 'the past is not simply a mirror for our own self-regard'. ${ }^{15}$ The reader may rightly be wary of what looks like cutting a random path of micro-history of ideas as the picturesque setting of a macro-historical paradigm change: the rational replacement of providence and eternal life in paradise by progress, welfare, and justice equated with humanitarian love. It may even look as if the hints in the direction that international law and human rights law today occupy roles and functions of symbolic reference and mediation that in

14 Some of the continuities of ideas are evoked in commentaries. Saint-Simon is typically mentioned in the context of first ideas for European economic integration and institutional developments, aside from l'abbé de Saint-Pierre and his ideas on confederation in Europe, see Juliette Grange, SaintSimon (1760-1825) (Paris: Ellipses, 2005), pp. 47-51. See also Koskenniemi, The Gentle Civilizer of Nations, pp. 266-352, on French 'solidarism' and international law.

15 Samuel Moyn, Human Rights and the Uses of History (London; Brooklyn, NY: Verso, 2014), p. xii. See also George Rodrigo Bandeira Galindo, 'Force Field: On History and Theory of International Law', Rechtsgeschicte 20 (2012): pp. 86-103. 
the past used to be accomplished by religion, are aimed as a demonstration of a 'truth' that nothing can really be secular, after all. My intentions lie elsewhere, however. In terms of today's renewed research interest in 'political theology', I suggest that Saint-Simon, Comte, and Durkheim are particularly stimulating intellectual figures-often neglected or caricatured. ${ }^{16}$ Each in his individual context was reacting creatively to what they saw as a crisis of societies and of religions, drawing new borders for the domains of politics (the political) and theology. ${ }^{17}$ Their idea - and others', such as Rousseau, of course-was to acknowledge the indispensable role of religion at the core of not only the social and moral but also the political collectivity, even up to the point of disowning the individual and her belief or its absence. ${ }^{18}$ At the same time, their emphasis on giving a sense and a direction to time, structured as a gradual human progress, is part of the story of how history became understood as universal, as a history of humanity. It is clear that their objectives as well as the inventions they offered for societal questions figure in many other parts of the different genealogies of international law, both before and after them: in theology, political science, philosophy, or economics. What matters here is how they presented their visionary products: working in the key moments of secularization, they insisted on picturing them as religions, underlining this by creating dogmas, symbolism, and ritual practices that evoked the traditional religions, in particular Christianity. Yet they declared the transcendental divinities dead. By that move the human individual, human communities, or humanity were further elevated yet declared 'positive', victorious over any superstition. In that sense, their religions aimed to capture the best of two worlds: secular and religious, rational and affective.

At the first sight, that modern and 'reasonable' appearance of their religions may render them appealing as sympathetic cousins of international law, free from the pejorative connotations of irrationality and mysticism. However, what difference does it make to see ideas, beliefs, faith, or commitment as religious or as something else, such as politics or ideology? I will return to this dilemma and to today's international law in my conclusions, focusing in particular on international criminal law and its institutional practice that are, to quote Frédéric Megret, 'for many international lawyers ... the ultimate test of global justice, a unique hope of

16 For example, Beiner's rich Civil Religion is silent on Saint-Simon and Durkheim and mentions Comte only in passing, in relation to Mill.

17 On the current heterogeneous understanding of what 'political theology' is, see, for example, Hent de Vries, 'Introduction', in Political Theologies, edited by Hent de Vries and Lawrence E. Sullivan (New York: Fordham University Press, 2006), pp. 25-7; Graham Hammill and Julia Reinhard Lupton, 'Introduction', in Political Theology and Early Modernity, edited by Graham Hammill and Julia Reinhard Lupton (Chicago; London: The University of Chicago Press, 2012), pp. 1-7; Elisabeth Phillips, Political Theology-A Guide for the Perplexed (London; New York: T\&T Clark, 2012).

18 See, for example, Karl Löwith's disapproving comments on Auguste Comte's 'neglect of individual destiny', Karl Löwith, Meaning of History (Chicago; London: The University of Chicago Press, 1949), p. 89; for claims on Durkheim denying human creativity and agency, see Steven Lukes and Andrew Scull, 'Introduction', in Durkheim and the Law, edited by Steven Lukes and Andrew Scull (Great Britain: Billing and Sons Ltd, 1983). 
redemption for the international legal order' ${ }^{19}$ To ground my conclusions, I will first discuss those parts of the work by Saint-Simon, Comte, and Durkheim that I find most relevant with regard to the questions evoked. My treatment is necessarily fragmentary and reductive. How they are presented here should not lead the reader to the mistaken impression that Saint-Simon, Comte, and Durkheim could or should be reduced to a harmonious trio behind a chronological evolution of a few key ideas - that would both flatten the richness and multiple influences of their individual work and disguise the major discontinuities and conflicts in their thinking. ${ }^{20}$

\section{Henri Saint-Simon}

A philosopher, economist, and forerunner sociologist, Henri Saint-Simon is associated with various ideas or developments: the scientific positivism that his assistant Auguste Comte later made famous under his own name, the historical method developed by Saint-Simon's pupil Augustin Thierry, (utopian) socialism and Marxism, international industrialism, the early seeds of European integration, and so forth. ${ }^{21}$ My interest here is in how Saint-Simon develops his vision of an improved society with social and economic well-being for all, in a manner that intertwines the roles his new religion, of industrialism, and increasing international cooperation and unity.

Saint-Simon was an adept at historical determinism, with a focus on physiological parallels. He believed that he could 'embrasser dans une seule conception tous les termes de la série des progrès de l'esprit humain, et cela d'une manière

19 Frédéric Megret, 'International Criminal Justice: A Critical Research Agenda', in Critical Approaches to International Criminal Law, edited by Christine Schwöbel (Abingdon: Routledge, 2014), p. 43.

20 The latter have been analysed in detail in a number of commentaries. On Saint-Simon and Comte, see, for example, Grange, Saint-Simon; Christian Laval, L'ambition sociologique (Paris: Editions La Decouverte \& Syros, 2002). On Durkheim and Comte, see, for example, Albin W. Gouldner, 'Introduction', in Emile Durkheim, Socialism and Saint-Simon (Ohio: The Antioch Press, 1958). On Saint-Simon's influence on Durkheim, see Steven Lukes, Emile Durkheim: His Life and Work-a Historical and Critical Study (Stanford, California: Stanford University Press, 1973); Roger Cotterell, Emile Durkheim: Law in a Moral Domain (Edinburgh: Edinburgh University Press, 1999).

21 See, for example, Pierre Musso, Saint-Simon et Saint-Simonisme (Paris: PUF, 1999); Pierre Ansart, Saint-Simon (Paris: PUF, 1969); Grange, Saint-Simon; Laval, Lambition sociologique, p. 3682. Marx in his writing appears both recognizant and critical of Saint-Simon, and particularly critical of his followers, the Saint-Simoniens. See, for example, Karl Marx and Friedrich Engels, Utopisme et communauté de l'avenir (Paris: François Maspero, 1976.); Karl Marx, The Capital, Volume III, pp. 431-4, https://www.marxists.org/archive/marx/works/download/pdf/Capital-Volume-III.pdf; see also Emile Durkheim, Socialism and Saint-Simon. On historicism: crediting Saint-Simon with the idea that with the correct theory, humanity would be able to intervene in creating its own future, Keith Taylor found this 'sufficiently original to justify the view of Saint-Simon as one of the founders of modern historicism'. Keith Taylor, The Political Ideas of the Utopian Socialists (Great Britain: Frank Cass and Company Limited, 1982). In the following, unless otherwise indicated, the references to Saint-Simon's work are to Oeuvres complètes, vols I-IV, edited by Juliette Grange, Pierre Musso, Philippe Régnier, and Frank Yonnet (Paris: PUF, 2012). 
piquante, en établissant une comparaison entre le développement moral de l'intelligence générale et celui de l'intelligence individuelle. ${ }^{22}$ His vision of the twelve phases of humanity that situates them analogically in relationship with the development of a human being ${ }^{23}$ is interesting for my argument here in several aspects. From 'primitive' to the feudal and the military society Saint-Simon described a childhood and puberty during which the organs necessary for the adult life of society gradually develop. A young child is concerned foremost with eating. Instead of producing, working, or fabricating, his primary occupation is to seize tasty food. ${ }^{24}$ The same holds true for primitive societies, where the lowest scale consists of individuals whose intelligence and memory 'n'etait guère plus étendue que celle du castor ou de l'éléphant'. ${ }^{25}$ To prevent puerile behaviour, repressive authorities in society are necessary up to the point when the child matures and gradually becomes reasonable. Saint-Simon sees a parallel to this evolution taking place in societies. Only when a human society reaches the age of majority, it can truly focus on producing, in a reasonable and peaceful manner, instead of instinctively merely satisfying its needs. ${ }^{26}$ In the childhood of a society, humans are ignorant, passionate in their reactions, and prone to all sorts of disorders and disturbances. The minority has to be organized militarily to keep the majority under control. The use of force is necessary to keep society together. 'Ainsi jusqu'à présent le principales forces de la société ont été employées à se maintenir en société, et les travaux ayant pour objet l'amélioration du bien-être moral et physique des nations n'ont pu et n'ont dû être considérés que comme des travaux accessoires. ${ }^{27}$ From the Middle Ages, a new principle of unification of society, taking shape with industrialization, entered into conflict with the ancient society. The broadening scope of education, employment, and an increasing desire for a peaceful life progressively make police forces, permanent armies, and spies redundant. The repressive and military components of the state were gradually transformed into administrating productive work. When societies turn adult, the moment is ripe to take conscience of the real telos of humans: no longer the domination of men over men but the collective exploitation of nature. Repression is no longer necessary. Secular happiness is at hand. The greatest achievement of this evolutionary march of civilization is precisely this: governed humans will manage to replace the principle of divine justice with that of the well-being of societies. This twelfth phase of evolution was, at the moment Saint-Simon was writing, to appear in the future:

22 Saint-Simon, Mémoire sur la science de l'homme, Oeuvres completes, II, p. 1135. See also SaintSimon, De l'organisation sociale, Oeuvres complètes, IV.

23 Saint-Simon, Mémoire sur la science, pp. 1129-59. Saint-Simon's presentation of civilization period by period was inspired by Nicolas de Condorcet's famous Esquisse d'un tableau historique des progrès de l'eprit humain (1794-95). Bibliothèque de Philosophie (Paris: Boivin, 1933). Before Condorcet, Turgot presented his Tableau philosophique des progrès successifs de l'esprit humain at Sorbonne in 1750 .

24 Saint-Simon, Mémoire sur la science, p. $1135 . \quad 25$ Ibid., p. 1130.

26 See Laval, L'ambition sociologique, pp. 68-70, based on Saint-Simon, De l'organisation sociale.

27 Saint-Simon, De l'organisation sociale, p. 3078. 
Le système général de nos connaissances sera réorganisé. Son organisation sera basée sur la croyance que l'univers est régi par une seule loi immuable. Tous le systèmes d'application, tels que les systèmes de religion, de politique, de morale, de législation civile, seront mis en accord avec le nouveau système de nos connaissances. ${ }^{28}$

How did Saint-Simon envisage this evolution taking place? The common thread throughout was the influence of ideas, in particular moral and religious ideas. At the heart of this was, to quote Durkheim's commentary Socialism and Saint-Simon, the 'sentiment of universal unity,'29 the two aspects of which are 'the idea of God and the idea of the fundamental law'. ${ }^{30}$ Saint-Simon's ideas grew increasingly visionary and political toward the end of his life. In Nouveau Christianisme ${ }^{31}$ he claimed a totally fresh start both for society and religion. J'accuse!, Saint-Simon repeated incessantly, accusing Catholics, in particular the Pope, the clergy, and Jesuits of being dangerous heretics. Protestants and Martin Luther were not much better valued. ${ }^{32}$ To remedy the alarming dissociation of economic progress and social cohesion-not only had the human species made no moral progress since Jesus Christ, it had retrograded — a new social morality for the new era had to be created, Saint-Simon argued. ${ }^{33}$ This moral had to be 'positive', in the sense of being contemporary to the age of science and industry, and widely shared. What were its components? The key was industrial progress, bringing maximum happiness to maximum people, echoing contemporary utilitarian ideas that were central to Saint-Simon in particular in his early writings. ${ }^{34}$ Nevertheless, mobilizing the affective and sentimental in human beings was the particular aim of Saint-Simon's new moral, thereby in his view strengthening sociability and solidarity. Even if this new industrial morality had to abandon previous theological representations, Saint-Simon underlined its continuity with Christianity. Pacification of men by the belief in a single God and fraternal love were the dogmas of Christianity that Saint-Simon valued most. ${ }^{35}$ In his new religion, they were to receive universal application, thereby supporting humans in their efforts to economic and technological progress globally, in particular for the poor.

The exact relationship of Saint-Simon's religion ('new Christianity')—that Durkheim qualified, as 'a doctrine of philanthropy having a pantheistic conception of the universe as its basis ${ }^{36}$ - to Christian religions remains ambiguous. The clearest differences appear to be its 'positive' and temporal character, its earthliness, the impersonality of the god figure, as well as the primary role given to morality, at the expense of creed, dogma, and clergy. ${ }^{37}$ This does not mean Saint-Simon did

28 Saint-Simon, Mémoire sur la science, p. 1153.

29 Durkheim, Socialism, p. 186.

${ }^{30}$ Ibid., p. 184

31 First published in 1825, Saint-Simon, Nouveau Christianisme, Oeuvres complètes, vol. IV.

32 Ibid., pp. 3196-222. $\quad 33$ Ibid., pp. 3222-4. See also Laval, Ambition, p. 74.

34 Saint-Simon, L'Industrie. See also Grange, Saint-Simon, pp. 41-7.

35 See Saint-Simon, L'Industrie, Oeuvres complètes II, pp. 1575-6 and Saint-Simon, Catéchisme des industriels, Oeuvres complètes IV, p. 2974.

36 Durkheim, Socialism, p. $193 . \quad 37$ Saint-Simon, Nouveau Christianisme, pp. 3191-2. 
not envisage a cult. Throughout his career Saint-Simon emphasized how society needed a sentimental and aesthetic cement that could be expressed in ceremonies and art. This spiritual component needed its specific organs. The first of them was the 'academy of sentiments', the purpose of which was to codify and perfect the sentiments useful for cohesion and social efficacy. ${ }^{38}$ The organs foreseen for the direction of intellectual production comprised artists and moralists tasked with generating presentations and pieces of arts that touched the affective. The various activities of cult had the purpose of making human beings feel their common existence.

For my reading here, the key message from Saint-Simon is the linkage of internationalism and economic development. In Durkheim's opinion, considering how little the phenomena was otherwise accorded attention in his time, it was Saint-Simon who 'prophesied the International'. ${ }^{39}$ Saint-Simon believed that ' $[t]$ he great moral movement which should make society pass from the modified despotic regime to one most advantageous to the majority of society' is necessarily 'common to the most enlightened peoples' ${ }^{40}$ Internationalism was essential in allowing nations to enter the stage of industrialism, for a people could disarm only if its neighbours, likewise, renounced militarism. SaintSimon also saw a still deeper reason for internationalism. It lay in 'a kind of political solidarity;' invisible bonds binding together nations at the same level of civilization that were, for Saint-Simon, manifest in the example of the Holy Alliance. ${ }^{41} \mathrm{He}$ envisaged an exit from feudal and military rule and a redirection towards an ideal of an international (European) concord or understanding by industry and an industrial spirit, integrating those who were 'united by the general interests of production, by the need they all have for security in work and liberty in exchange. The producers of all countries are therefore essentially friends'. ${ }^{42}$ Saint-Simon called for an international (European) organization that would contribute to establishing, in each particular society, the industrial system. The organization was not destined to remain forever restricted to the European continent. It would gradually embrace all humanity, since 'the industrial regime will be the ultimate organization of the humankind'. ${ }^{43}$ The future would see the formation of a society that included all men. It would undertake the systematic exploitation of the earth, the territorial property of human kind. ${ }^{44}$ However, as Durkheim pointed out, this was 'but a dream which is dear to him and which, from time to time, crosses his mind-but which he does not conceive as realizable for the present'. ${ }^{45}$

38 Saint-Simon, Catéchisme des industriels, pp. 2988-91.

39 Durkheim, Socialism, pp. 174-5.

40 Saint-Simon, Système industriel, V, p. 80, referred to by Durkheim, Socialism, p. 170.

41 Saint-Simon, Système industriel, VI, pp. 99-100, referred to by Durkheim, Socialism, p. 170.

42 Saint-Simon, Système industriel, III, p. 47, referred to by Durkheim, Socialism, p. 172.

43 Saint-Simon, Système Industriel, Oeuvres complètes III, p. 2421.

44 Saint-Simon, Nouveau, pp. 3190, $3194 . \quad 45$ Durkheim, Socialism, p. 175. 


\section{Auguste Comte}

Comte started his professional life as an assistant of Saint-Simon who was an everpresent influence on his thinking. ${ }^{46}$ Often credited as the 'founder of positivism' and one of the 'fathers of sociology', Comte produced a voluminous and opaque oeuvre. His areas of interest ranged from philosophy to politics, religion, social sciences, and, in particular, the role of scientific progress for the future of humanity. Several commentators see the oeuvre of Comte as divided into two parts: The first focusing on establishing a 'history of the intelligence of the objective world,' while the second part is Comte's sociology of the sentiment of sociability, culminating in the invention of the 'religion of Humanity'. ${ }^{47}$

My attention focuses on how Comte advocated unity, human and social, in particular the sense of coherence of shared human history that lay at the foundation of his religion. How did he articulate the fact that 'united' humanity had to be directed by the Europeans - and with such a heavy hand? Comte's method to understand history was based on an evolutionary model of law of three ages. ${ }^{48}$ 'Lesprit human', which John Stuart Mill—Comte's close support and correspondent for a few years ${ }^{49}$ - interpreted to refer to 'every distinct class of human conceptions, ${ }^{50}$ passes through three successive stages: theological (divided into fetishism, polytheism, and monotheism), metaphysical, and positive. ${ }^{51}$ By positivism Comte meant the acceptance by humans that it was impossible to acquire absolute notions concerning the origins and destiny of the universe or phenomena. Invariable laws governed all phenomena, with which no volitions, either natural or supernatural, interfere. By combining reasoning and observation in the progress of science, these laws could be discovered. ${ }^{52}$ The turn to positivism was, for Comte, the terminal moment in human history.

46 Several commentators have pointed out how Comte failed to adequately recognize this; see Laval, Ambition, p. 86 and fn. 3. Löwith, Meaning, pp. 91-2: 'There is little in Comte's ideas that cannot be traced back to either Saint-Simon, Condorcet, or Turgot.' For biographical accounts of Comte, see, for example, Mary Pickering, Auguste Comte: An Intellectual Biography, vols 1-3 (Cambridge; New York: Cambridge University Press, 1993, 2009); Henri Gouhier, La vie d'Auguste Comte (Paris: Gallimard, 1931).

47 John Stuart Mill, Comte's close correspondent in his early career, considered the second part 'false and misleading'; see John Stuart Mill, Auguste Comte and Positivism (London: Trübner, 1866), p. 5. Mill's Three Essays on Religion (1874) later faced similar reactions, see Beiner, Civil Religion, p. 268-75. On the division of Comte's work, see also Raymond Aron, Les étapes de la pensée sociologique (Paris: Gallimard, 1967), pp. 79-80; Laval, Ambition, pp. 122-4.

48 The idea of the three ages was first presented in Comte, Opuscules and developed in Cours de philosophie positive, I, reprinted in Auguste Comte, Philosophie des sciences, edited by Juliette Grange (Paris: Gallimard, 1996), pp. 52-6.

49 Their correspondence is published as Lettres inédites de John Stuart Mill à Auguste Comte (Paris: Alcan, 1899).

${ }_{50}$ Mill, Auguste Comte.

51 Comte, Troisieme opuscule: Considérations philosophiques sur les sciences et les savants (1825), http://classiques.uqac.ca/classiques/Comte_auguste/la_science_sociale_extraits/1_opuscules_philo_ soc/opuscules_philo_sociale.pdf (last visited 8 June 2015).

52 Cours de philosophie positive, I, reprinted in Comte, Philosophie des sciences, pp. 52-6. For analysis, see, for example, Mill, Auguste Comte; Aron, Les étapes, pp. 81-3. 
For Comte, the history of Europe absorbed in itself the history of the human species. He saw industrial society-the society of Western Europe-as the exemplar for the rest of humanity, in particular in how to acquire prosperity and power. The telos of the united human history was the development and blossoming of human nature, progressing from generation to generation. Comte was satisfied that his historical method added the key idea of solidarity between human generations to the general ideas of solidarity between social classes. ${ }^{53}$ Humanity was defined primarily by its intellectual and moral nature, by the capacity to accumulate cultural and material treasures. 'La grande sociéte mondiale' was constituted of micro-societies of families, towns, and 'nationalités libres et durables' that were compact societies-'petites Humanités' - gradually replacing modern states too large to unite people, and humanity. ${ }^{54}$

Faced with the irreversibility of individualization, Comte sought something that could nevertheless represent humanity as a whole, supported by institutions, constituting a 'force spécialement destinée à y ramener aux vues et aux sentiments d'ensemble des agents qui tendent toujours à s'en écarter'. ${ }^{55} \mathrm{He}$ believed that the sentiments of sociability of humans were not only an essential factor of morality but also a constitutive part of the human species. ${ }^{56}$ Comte did not think highly of individual human rights or legal regulation, in general. The broad lines of historical development demonstrated, for him, how egoism was to regress owing to the biological evolution of the instinct of sympathy and the blooming of the positive spirit. Progress for Comte was not essentially economic, but moral, sentimental, and intellectual. ${ }^{57}$ It was manifest in the development of universal love and altruism, in an orientation towards a collective happiness. ${ }^{58}$ This progress culminated in the 'religion of Humanity'.

In Comte's view, a religion was necessary because of the chaos of varying and contrasting interests, both at the individual and societal level. Only a powerful sentiment towards an external object that intelligence recognised as transcending rivalling and conflicting tendencies could create an accord. Psychological and physical health required the recognition of a superior authority capable of imposing firm rules for private and collective conduct. ${ }^{59}$ That is why the problem posed by 'la désuétude de Dieu' had to be solved. The new religion of Humanity 'irrevocably eliminated the conception of God'60 and advantageously replaced the 'insufficient

53 Comte positions his focus on history in contrast to 'sectes rénovatrices' whose 'esprit antihistorique suppose toujours une société sans ancêtres', Auguste Comte, Discours sur l'ensemble du positivisme [1848] (Paris: Flammarion, 1998), p. 193.

54 See Grange, La philosophie, pp. 296, 319-24.

55 Comte, Catéchisme positiviste (1825), p. 205.

56 See, Comte, Discours, p. 245. See also Pierre Arnaud, La sociologie de Comte (Paris: PUF, 1969), pp. 132-3.

57 See Comte, Discours, pp. 235-300. On the concept of progress in Comte's work in general, see Löwith, Meaning, pp. 67-91.

58 Comte, Discours, pp. 352-4.

59 Auguste Comte, Systeme de politique positive, II (Paris: Libraire positiviste, Georges Crès et Cie, 1851-54), p. 8.

60 Comte, Discours, p. 353. 
fiction of Christ' ${ }^{61}$ Comte was very critical of Christianity, and Protestantism in particular. He accused it of having favoured modern egoism, to the detriment of collective orientation. Here Comte departed from Saint-Simon. The Christian love for your brother valued highly by Saint-Simon was, for Comte, just a roundabout way for an individual to guarantee her own salvation by good deeds, by obeying obligations and commands. ${ }^{62}$ Christians were preoccupied with themselves, they did not truly care for the fate of others, Comte argued. In contrast, the Comtean 'religion of Humanity' offered collective salvation, by unifying dispersed humans, and promoting a unique centre that embraced 'la raison, l'imagination et le sentiment'. ${ }^{63}$

Comte emphasized how humanity needed dogmas, rites, and myths that were explicitly religious but positivist, and secular. He described them as 'mèta-religieux', based on a moral cognisance of the historic role of religions and the general history of civilization. ${ }^{64}$ Their task was to condense the social sentiment, the spirit of being together. ${ }^{65}$ This was also served by the 'new fetishism' of the religion of Humanity: the new god 'le Grand-Etre' ('the Supreme Being'); the fetish of world and space called 'Grand Milieu'; and that of the Earth called 'Grand Fetish'. ${ }^{66}$ Comte's Supreme Being possessed a double quality. It figured as an objective being outside each individual, as a reality with its own laws. It was also the cultural or symbolic organism to which each individual aspired to adhere by his accomplishments. ${ }^{67}$ Comte's religion also involved a cult and organization inspired by the Catholic one. ${ }^{68}$

Like Saint-Simon, Comte aspired to combine altruism with social and economical cooperation in a new manner. Whereas previous religions called for contemplation and inactivity, the religion of Humanity pushed to actively realize the good. ${ }^{69}$ In this spirit, it also set limits of conduct on the political and economic spheres, military contest, excessive individualism, destructive exploitation of nature, or spoiling of the human patrimony. The religion of Humanity encouraged participation and universal cooperation by considering les hommes non comme autant d'êtres séparés, mais comme les divers organes d'un seul Grand-Etre' ${ }^{70}$ But were all human beings equal organs of the Supreme Being? Comte was writing at the juncture of the dissolution of the colonial empires constituted in the sixteenth to

${ }^{61}$ Comte, Système de politique positive, I, p. 411.

62 Comte, Discours, pp. 182-3.

63 Ibid., p. $356 . \quad 64$ See Grange, La philosophie, p. 18.

65 See analysis by Laval, Ambition, p. 134.

66 See Grange, La philosophie, pp. 358-68 who offers analysis and multiple references to Comte's treatment of these figures that I am not able to address in detail. See also, Andrew Wernick, Auguste Comte and the Religion of Humanity: The Post-theistic Program of French Social Theory (Cambridge;

New York: Cambridge University Press, 2001).

67 Comte, Système de politique positive, II, p. 68.

68 Mill qualified Comte's religion as 'une forme de catholicisme sans christianisme', Grange, La philosophie, p. 18. For a comparison with Durkheim's religion, see W. S. F. Pickering, Durkheim's Sociology of Religion (Cambridge: James Clarke \& Co, 2009), pp. 483-7. On Comte's emphasis on a private cult rather than a public one, see Grange, La philosophie, pp. 401-13.

69 Comte, Discours, p. 386.

${ }^{70}$ Ibid., p. 387. See also analysis by Laval, Ambition, p. 137. 
eighteenth centuries and the creation of the empires of the nineteenth century. His thoughts on race, universality, and international governance appear ambivalent to today's reader. ${ }^{71}$ Comte envisaged how in the future les cinq cents sociocraties partielles du globe régénéré composent la république universelle, après un concours toujours libre'. ${ }^{72}$ The 'Comité positif occidental' was to be European first, but get enlarged progressively to other continents and institutes as a global 'pouvoir sprituel' and, in the course of two centuries, an international society. ${ }^{73}$ Comte however did not foresee society as a way of political organization but as a contract of morality and of faith. ${ }^{74}$ In his critique of past colonialism, Comte argued that it had rendered evident the radical failure of the politics of systematically destroying human races, in the powerlessness to assimilate them..$^{75}$ Thereby it had demonstrated that progress was meant to gradually concern the whole of humanity. By stimulating the importance of the military and the risk of war, the colonial expansion tragically contrasted Comte's schemas of evolution according to which war in the developed industrial societies, 'elite of humanity,' ${ }^{76}$ became an anachronism. Regretting humanity's 'inevitable primitive tendency', Comte nevertheless continued to see as its 'final destination, not less irresistible, an essentially industrial life'. ${ }^{77}$ Comte looked forward to further institutional developments in Europe to rectify the 'provisory default of any systematic organisation of international relations,' celebrating 'our industrial and pacific instinct' that was constantly striving towards 'the fundamental rest of the civilized world'. ${ }^{78}$ Comte had a strong emphasis on unity of human history, dear to evolutionists in general. As Raymond Aron critically points out, Comte, even if also known as the creator of scientific positivism, advocated thinking that could be seen as reminiscent of providentialism: the inevitable course of history is advancing on its line of evolution that is fixed either by religion or by the nature of humans. ${ }^{79}$ In Comte's religion of humanity, the trans-generational continuity played a key role. The dead, the living, and those who will be born form together, in the relations between them, the cyclical humanity. Comte laid much weight on the ideas of intergenerational fidelity and gifts between generations, of the dead to current and future generations and vice versa, as well as the call to make generations feel both the weight and the honour of those gifts. ${ }^{80}$ The goal of

${ }^{71}$ For comments on this, see Löwith, Meaning, p. 232.

72 Comte, Système de politique positive ou traité de sociologie instituant la religion de l'Humanité, IV, edited by Carilian-Goeury Mathias and V. Dalmont, 5th edn (Paris: Siege de la Société Positiviste, 1929 [1851-54]), p. 355.

73 Comte, Système de politique positive, p. $392 . \quad{ }^{74}$ See Grange, Philosophie, p. 322.

75 Auguste Comte, Cours de philosophie positive, Euvres VI (Paris: Les Editions Anthropos, 1968), p. 68.

76 Ibid., p. 239. See also Raymond Aron, La société industrielle et la guerre (Paris: Plon, 1959).

77 Comte, Cours de philosophie positive, p. 375.

$78 \mathrm{Ibid}$. Aron is critical of this excessive optimism: Comte 'a devalorisé les conflits idéologiques dont on vécu les sociétes européennes et dont tant de millions de gens sont morts'. Aron, Les étapes, p. 95.

79 Aron, Les étapes, p. 97, 103. See also Löwith, Meaning, pp. 71-4.

80 The continuity of the maxim 'rendre à autrui ce que l'on a recu' from Saint-Simon to Comte to Durkheim and Mauss, see Laval, Ambition, p. 137. 
human action was, in Comte's view, the subjective immortality in the memory of the posteriority. ${ }^{81}$

Since Comte's time, 'progress' has become, for many, a word 'entangled with a history of racism and Eurocentric self-congratulations' ${ }^{82}$ Yet the idea of universal progress by law and institutional legal practices remains the underlying premise of much international law thinking. ${ }^{83}$ Intergenerational transfer is also a central element of international law and the epistemic community of international lawyers. Not only in celebratory speeches or festschrifts but also in law journal articles and commentaries, the 'international criminal justice system' is accorded a status above historicity, breaking free from the contingent, temporally, and socially situated character of currently held beliefs and values, of today's random institutions and practices. ${ }^{84}$ It is a gift that past generations hand to future ones. For Comte, the subjective trans-generational element figured at the source of all transcendence, but until the emergence of the 'religion of Humanity' it had been travestied in the theory of immortality of souls promoted by previous theologies. ${ }^{85}$

\section{Emile Durkheim}

In contrast, Emile Durkheim saw value in the antithesis of body and soul, the immortal soul being 'useful in rendering intelligible the continuity of the collective life' ${ }^{86}$ The protecting ancestors were, for Durkheim, to be interpreted amongst other external projections of the individual soul, representing 'an outside power, superior to us, which gives us our law and judges us, but which also aids and sustains us' ${ }^{87}$ Durkheim was the first professor of sociology in the world, at Sorbonne University, and an important public figure in France. ${ }^{88}$ His major publications include The Division of Labour in Society, Suicide, The Rules of Sociological

81 Comte, Système de politique positive, IV, p. 35.

82 Bruce Robbins, Feeling Global: Internationalism in Distress (New York; London: New York University Press, 1999), p. 123.

${ }^{83}$ For analysis, see, for example, Thomas Skouteris, The Notion of Progress in International Law Discourse (The Hague: T.M.C. Asser Press, 2010); Nathaniel Berman, 'In the Wake of Empire', American University International Law Review 14 (1999): p. 1515.

${ }_{84}$ See, for example, M. Cherif Bassiouni's speech in the ceremony for the opening of signature of the Rome Treaty, in Bassiouni, The Statute of the International Criminal Court: A Documentary History (Ardsley, NY: Transnational Publishers, Inc., 1998), at xxi; Claus Kreß, 'Towards a Truly Universal Invisible College of International Criminal Lawyers', FICHL Occasional Paper Series, no. 4 (2014), https://www.legal-tools.org/doc/82bf10/ (last visited 15 April 2015).

${ }_{85}$ See Comte, Discours, pp. 371-2.

86 Emile Durkheim, Les Formes élémentaires de la vie religieuse (1912), references here to the translation The Elementary Forms of the Religious Life,7th edn (London: Allen \& Unwin, 1971), p. 269.

87 Durkheim, The Elementary, p. 280.

${ }^{88}$ For biographical accounts, see M. Fournier, Emile Durkheim 1858-1917 (Paris: Fayard, 2007); Steven Lukes, Emile Durkheim: His Life and Work- a Historical and Critical Study (London: Allen Lane the Penguin Press, 1973). See also Jeffrey C. Alexander and Philip Smith, 'Introduction: the new Durkheim', in The Cambridge Companion to Durkheim, edited by Jeffrey C. Alexander and Philip Smith (Cambridge: Cambridge University Press, 2005). 
Method, several publications on education, as well as on religion, most famously The Elementary Forms of Religious Life. ${ }^{89}$ Durkheim also broadly addressed the historical evolution of law, 'the origins of law' as he called it, and defended his central methodological view of law as an index of social solidarity. Of the three thinkers discussed, only Durkheim explicitly focused on questions of crime and punishment. ${ }^{90}$ Not that he was interested in utilitarian criminological theories, fashionable in his time. Instead, he gave crime and criminal law a special social role in his general evolutionary theories on society, the intertwined causalities of the division of labour in society, social solidarity, and common morality. Durkheim is not known for having directly worked on international criminal law, but appeared sensitive to the underlying ideas of accountability for and in armed conflict. ${ }^{91} \mathrm{My}$ analysis will focus on his ideas on social solidarity and criminal law, in particular how collective expressions of affects relate to morality and law.

Durkheim and his closest colleagues were preoccupied with the religious origins of all social phenomena, including criminal law.92 But what was religion for Durkheim? His definition of it as 'a system of ideas by means of which individuals represent to themselves the society of which they are members, and the obscure but intimate relations which they have with it' was indebted, on Durkheim's own account, to Robertson Smith and his school, as well as 'the ethnographers of England and America'. ${ }^{93}$ Smith's view of religion as 'a relation of all the members of a community to the power that has the good of the community at heart ${ }^{94}$ was adopted by Durkheim, as well as the conviction that 'religion did not exist for the saving of souls but for the preservation and welfare of society'. ${ }^{95}$ Durkheim's sociology of religion differed in focus from that of his contemporary, Max Weber (1864-1920). Each of them acknowledged both the central force of religion in societies in general and the declining role of traditional religions in modern societies. Yet they presented differing interpretations for the consequences of this. Weber addressed rationalization, intellectualization, and the growing importance accorded to sciences as disenchantment with the world and emphasized the legal-rational foundations of authority and the role of bureaucratic governance in modernity. ${ }^{96}$

89 For a bibliography of Durkheim, see Lukes, Emile Durkheim, pp. 561-90.

90 Dispersed in several pieces of work not dealing primarily with criminal law, see, for example, The Division of Labour in Society (New York: Macmillan, 1984, re-edited New York: The Free Press, 1997); Moral Education (New York: The Free Press of Glencoe, 1961); 'Two Laws on Penal Evolution', reprinted in Economy and Society 2, no. 3 (August 1973): pp. 285-308; Individualism.

${ }^{1}$ As suggested by biographical accounts, Durkheim's public positions on WWI, and the last orientations of his research. I am touching upon this in Immi Tallgren, 'The Durkheimian Spell of International Criminal Law?', in Revue interdisciplinaire d'études juridiques 71 (2013): pp. 157-89.

92 See Paul Huvelin, 'Magie et droit individuel', L'Année sociologique, (1905-06); Marcel Mauss, La religion et les origines du droit pénal d'après un livre récent, Oeuvres, 2 . Representations collectives et diversité des civilisations (Paris: Les editions de minuit, 1968), pp. 651-98.

93 Durkheim, 'Deploige, Simon, Le conflit de la morale et de la sociologie', L'Année sociologique XII (1913): pp. 326-8, at p. 326. For analysis, see Lukes, Emile Durkheim, pp. 237-44, 450-84. Lukes highlights also the influence of Fustel de Coulanges, p. 450, fn 1.

${ }_{94}$ Robertson Smith, Lectures on the Religion of the Semites (Edinburgh: 1889; 3rd edn, London: 1927), p. 55. Quoted by Lukes, Emile Durkheim, p. 450.

${ }_{95}$ Smith, Lectures, p. 32.

96 Max Weber, Theory of Social and Economic Organization (New York: Free Press, 1947). 
In contrast, Durkheim turned to developing ideas where both society and the individual acquire a religious character, as discussed in the following.

In The Division of Labour (first published in 1893), Durkheim presented an evolutionary theory where social solidarity is gradually transformed from mechanical to organic due to changes in the division of work in society and other factors, in particular a greater role for science. These societal developments lead towards a regression of traditional religions or religiousness. However, a foundation of underlying moral principles that meet with consensus in society remained crucially important, even in modernity. The repressive law was a partial reflection of the conscience collective, the 'totality of beliefs and sentiments common to the average members of a society, internalized by its members. ${ }^{97}$ Durkheim pictured crime as a violation of collective sentiments and punishment as an expression of them: 'Crime disturbs those feelings which in any one type of society are to be found in every healthy consciousness.' ${ }^{8}$ 'The main function of punishment was not prevention but maintaining cohesion intact. Crime and punishment contribute to social integration, in so far as crime elicits punishment which in turn reaffirms and reinforces collective beliefs and sentiments and thereby social solidarity. ${ }^{99}$ Whereas crimes of different types exist, what mattered was the reaction that they provoked: 'they strike the moral consciousness of nations in the same way and universally produce the same consequence'. 100

In Division, Durkheim pictured an evolution where the progress of division of labour diminished the collective sentiments and thereby the need for repression, replaced by restitutive law. One could perhaps see Saint-Simon's influence here. But in 'L'Individualisme et les intellectuels' (1898) Durkheim turned to argue that individualism and distributive justice involved not the abandonment but the transformation of collective beliefs and sentiments, whose need for penal expression and reinforcement survived. Punishment was protecting moral values even in a secular modern society of organic solidarity, and nourishing itself from the expressions of reprove. ${ }^{101}$ In 'L'Individualisme et les intellectuels', Durkheim took the defence of individualism targeted in the public campaign against the defenders of Dreyfus. To counter the accusations of the 'egoistic cult of the self', Durkheim emphasized how for both Kant and Rousseau, referred to by Durkheim as the spiritualistes, 'the only ways of acting that are moral are those which are fitting for all men equally, ... implied in the notion of man in general'. ${ }^{102}$ In Durkheim's reading, this ideal surpassed the limit of utilitarian ends so greatly that those holding the ideal experienced it as marked with a religious character. He considered the human person

97 Durkheim, The Division, pp. 38-9. $\quad 98$ Ibid., p. $34 . \quad 99$ Ibid., pp. 60-3.

100 Ibid., p. 31.

101 Durkheim, Individualism. For commentaries, see, for example, Roger Cotterell, Emile Durkheim: Law in a Moral Domain (Edinburgh: Edinburgh University Press, 1999); Lukes and Scull, Durkheim, pp. 15-19; Jeffrey C. Alexander and Philip Smith, 'Introduction: the new Durkheim', in The Cambridge Companion to Durkheim, edited by Jeffrey C. Alexander and Philip Smith (Cambridge: Cambridge University Press, 2005).

102 Durkheim, Individualism, p. 61. 
as sacred ... It has something of that transcendental majesty which the churches of all times have given to their Gods. It is conceived as being invested with that mysterious property which creates an empty space around holy objects, which keeps them away from profane contacts and which draws them away from ordinary life. ${ }^{103}$

Once the confusions clarified between individualism and utilitarianism, the 'religion of humanity whose rational expression is the individualist morality' ${ }^{104}$ appeared. Durkheim argued that religion essentially was 'nothing else than a system of collective beliefs and practices that have a special authority'. Symbols and rites, or temples and priests were only superficial aspects. Durkheim attributed the evolution towards his new religion to two factors. Territorially extended societies caused plasticity and instability of traditions and practices, and the advancing division of labour made men's minds differ in a growing manner. Once particular religious rites and prejudices disappeared,

there remains nothing that men may love and honour in common, apart from the man itself. This is why man has become a god for man, and it is why he can no longer turn to other gods without being untrue to himself. And just as each of us embodies something of humanity, so each individual mind has within itself something of the divine, and thereby finds itself marked by a characteristic which renders it sacred and inviolable to others. ${ }^{105}$

From the religiousness vested in the human person it followed that '[w] hoever makes an attempt on a man's life, on a man's liberty, on a man's honour inspires us with a feeling of horror.' 106 Violations could not occur without eroding the sentiments they violated. As these sentiments were all that individuals still had in common, they could not weaken without disturbing the cohesion of society: 'A religion which tolerates acts of sacrilege abdicates any sway over men's minds.' ${ }^{107}$ Durkheim here appears partly to meld his previous ideas on criminal law into his religion, as part of his move from functionalism towards a more symbolic understanding of society. ${ }^{108}$ Expressions of reproof were simultaneously representations of the Durkheimian secular religion.

Durkheim later abandoned explicit analysis of the religion of individual, society or humanity, but elements of the combination of individualism, rationalism and collective sentiments towards society and humanity appear scattered in Durkheim's later writings. ${ }^{109}$ In The Elementary Forms, a study on the religiousness of Australian aboriginals but to which Durkheim himself gave a more general bearing, he emphasized how all societies generate belief-systems which hold certain beings and activities as sacred. Among modern forms of this were 'the sacred character' accorded to 'princes, nobles, and political leaders', the belief in progress and the commitment to free inquiry, which is itself 'untouchable, that is to say ... sacred'. ${ }^{110}$ For Durkheim, there was something 'eternal in religion which is

103 Ibid., p. $62 . \quad 104$ Ibid., p. $67 . \quad 105$ Ibid., p. $67 . \quad 106$ Ibid., p. 62.

107 Ibid., p. 69.108 See, for example, Alexander and Smith, 'Introduction'.

109 See, for example, Pickering, Durkheim's Sociology, pp. 503-21; Lukes, Emile; Camille Tarot, De Durkheim à Mauss, l'invention du symbolique (Paris: Editions la Découverte/M.A.U.S.S., 1999), p. 213.

110 Durkheim, The Elementary, p. 213. 
destined to survive all the particular symbols in which religious thought has successively enveloped itself'; no society could exist without 'the need of upholding and reaffirming at regular intervals the collective sentiments and the collective ideas which make its unity and its personality'. ${ }^{11}$ Durkheim was convinced that 'a society has all that is necessary to arouse the sensation of the divine in minds' ${ }^{112}$ Society was exercising moral authority and required obedience, while at the same time exercising a stimulating influence towards what was good and benevolent. ${ }^{113}$ Durkheim evoked the possibly of faux semblante: the commitment and admiration felt for the society and its moral norms could be 'so closely related to the religious sentiment that many people have confounded the two'. The moral power conferred by public opinion and that with which sacred beings, objects or institutions were invested were 'at bottom of a single origin and made up of the same elements' ${ }^{114}$ Societies were constantly creating sacred out of the ordinary, be it by sacralizing founding texts or deifying leaders. ${ }^{115}$

As Beth van Schaack observes, 'many ICL cases proceed as though a transcendent law exists that has yet to be reduced to positive law but that can be discovered and invoked in criminal proceedings'. ${ }^{116}$ Durkheim's work has recently served as an inspiration for the analysis of suggestions that international criminal law condenses how moral values and beliefs of a global community are present in international law and guide its application. ${ }^{117}$ They are no longer expressed, as in the early days of international criminal law, in terms of 'values which are immutable and eternal' in the light of the 'Christian-Judaic absolutes of good and evil,' or as a result of the 'universal brotherhood under the fatherhood of God'. ${ }^{118}$ Even in their more neutral appearance, such as the 'principle of humanity which has recently taken centre stage in international law debates,' 119 international criminal law and its institutions appear as the most visible and powerful incarnations of this, symbolizing 'morality' and 'justice'_and thereby, also 'love' ${ }^{120}$ — in international law.

111 Ibid., p. 427.

112 Ibid., p. 206.

113 Ibid., pp. 211, 212.

114 Ibid., p. 213.

115 I am not able here to discuss this in comparison to Weber's ideas on charisma as extraordinary power and grace ascribed to certain individuals and institutions, see Weber, Theory, nor more recent elaborations, see, for example, Edward Shils, The Constitution of Society (Chicago: University of Chicago Press, 1982). See also Clifford Geertz, 'Centers, Kings and Charisma: Reflections on the Symbolics of Power', in Local Knowledge: Further Essays in Interpretative Anthropology (New York: Basic Books, 1983); David Kertzer, Ritual, Politics, and Power (New Haven, CT; London: Yale University Press, 1988).

116 Beth van Schaak, 'Crimen sine lege: Judicial Lawmaking at the Intersection of Law and Morals', Georgetown Law Journal 97 (2008-09): p. 157.

117 See Salif Nimage, 'An International Conscience Collective?', International Criminal Law Review 7 (2007): pp. 561-619. For a more reserved view, see Roger Cotterrell, 'The Concept of Crime and Transnational Networks of Community', in Globalisation, Criminal Law and Criminal Justice, edited by V. Mitsilegas, P. Alldridge, and L. Cheliotis (Oxford: Hart, 2015).

118 Joseph B. Keenan and Brendan F. Brown, Crimes Against International Law (Washington, Public Affairs Press, 1950), pp. vi, vii, and 72, referred to by Nimage, 'An International Conscience'.

119 Isabel Feichtner, 'Realizing Utopia through the Practice of International Law', European Journal of International Law 23 (2012): p. 1143, at 1154. See also Teitel, Humanity's Law.

120 See Jean-Luc Nancy, 'Church, State, Resistance', in Political Theologies, edited by Hent de Vries and Lawrence E. Sullivan (New York: Fordham University Press, 2006), pp. 111-12. 
In such a reading, international criminal trials figure amongst the ways of revivifying 'the most essential elements of the collective consciousness', so that an international community 'periodically renews the sentiment which it has of itself and of its unity'. ${ }^{121}$ The international trials, relayed globally by way of outreach activities and media, may aspire to functions Durkheim accorded to religious practices: 'representing or imprinting [the past] more deeply in the mind'. ${ }^{122}$ When 'a society is going through circumstances which sadden, perplex or irritate it, ${ }^{123}$ religiousness is representing society in the sense of expressing these social realities.

\section{Conclusions}

Saint-Simon's, Comte's, and Durkheim's religions of humanity and international law all present features of a system of communication of ideas and sentiments; they involve specifying and regulating social relationships by expressive means. In their different ways, they strive to create a sense of shared history where humans can learn from their experiences and evolve constructively. Also shared is how communicating ideas and sentiments and regulating social relationships require effort. Think of, for example, how Auguste Comte emphasized the role of civic education in spreading the religion of humanity. He developed elaborate dogmas and symbols of humanity, as well as a flag and temples of humanity for commemoration. International law and its institutional practice create and evoke dogmas and symbols manifest in the traditions of assembly, procedure, language, and attire, or in the memorabilia and forums of commemorating moments of institutional creation, law-making, or famous trials or crimes. In international institutions' communication, outreach and media policies have an important role. Fetishism or not, great care is put on the material dimension of institutional presence, as, for example, demonstrated by the new International Criminal Court (ICC) headquarters. The ICC building complex under construction in The Hague is intended to convey 'the eminence and authority of the ICC, while at the same time relating it on a human scale', making 'visible to anyone and everyone' that the ICC has 'become a cornerstone of international justice and the modern global civilization by making known to the remotest corners of the world that the most serious crimes do not go unpunished anymore'. ${ }^{124}$

Just as Durkheim identified the 'recreative and aesthetic element' of religions, comparing rites to 'dramatic representations', ${ }^{125}$ Comte foresaw 'free missionaries who would preach everywhere the universal doctrine'. ${ }^{126}$ Would Saint-Simon have

121 Durkheim, The Elementary, p. 375.

122 Ibid., pp. 376, 378.

123 Ibid., p. 419.

124 Statement by H.E. Ambassador Markus Börlin, Vice-President of the Assembly of States Parties, 16 April 2013 http://www.icccpi.int/en_menus/icc/press\%20and\%20media/press\%20 releases/Documents/pr898/Groundbreaking-Ceremony-ASP-Vice-President-Statement.pdf (last consulted 14 April 2015).

125 Durkheim, The Elementary, pp. 379-83.

126 Comte, Systeme de politique positive I, p. 387. 
let international lawyers enter his 'academy of sentiments', indispensable in secular societies? David Luban recently has suggested that 'moral learning' by international criminal law becomes 'common property of humankind' in which positive complementarity and outreach activities are supposedly 'helping to devolve norms to local institutions'. ${ }^{127}$ Is it not such sympathetic thoughts towards the local that, by making palpable the distance that characterizes how international law relates to everyday lives, accentuate its resemblance with religion in terms of faith in its positive potential to bring about changes, if not miracles? Just as 'the world of religious things is a partially imaginary world,' therefore lending 'itself more readily to the free creations of the mind,' 128 the fact that international law addresses issues that are vast and cumbersome to comprehend may render it easier to believe-even in 'things' that would seem absurd in closer circles, nationally or amongst people known personally.

It is in particular the symbolism of condemning and punishing disgraced national leaders and their era that may take dramatic features as a culmination of the eschatological anticipation of a future salvation, as if correcting the (totalitarian, nationalistic) past in a judgement by international judges-priests. At the same time, it may appear as a neutral way for an international community to become conscious of itself and to assure the continuation of this consciousness, sociological characteristics that Durkheim accorded to religion. ${ }^{129}$ The mechanisms of international law contribute to forming an international authority, be it moral or political, with contingent direction and programme. For Durkheim, an individual believer feels within him more force, to endure the trials of existence or to conquer them. In current times, could one see international law as part of the fragile but sympathetic symbolic structures by which an individual manages to rise 'above the miseries of the world, ... above his condition as a mere man'? ${ }^{130}$ If not yet then in the future, international law would stand for the chance that the believer will finally be saved from evil, under whatever form he conceives the evil. After all, 'the first article in every creed is salvation by faith'. ${ }^{131}$

But the mirror is splintered. As the utopian aspirations of current international law and its institutional practice figure, to quote Antonio Cassese, 'gradually [to] transform world society into a really international community endowed with paramount communal values and at least a modicum of community institutions so that public or collective concerns may prevail over private interests'. ${ }^{132}$ Cassese's language on common values, collective concerns, and institutions based on values echoes Saint-Simon, Comte, and Durkheim. Yet the ambition today is elsewhere. More than the international economic institutions or development agencies, immersed in their complicity or perceived inefficacy, it is human rights and the

127 David Luban, 'After the Honeymoon', Journal of International Criminal Justice 11 (2013): p. 512.

128 Durkheim, The Elementary, p. 381 (italics added). $\quad{ }^{129}$ Ibid., p. 231.

130 Ibid., p. $416 . \quad 131$ Durkheim, The Elementary, p. 416.

132 Antonio Cassese, 'Introduction', in Realizing Utopia: The Future of International Law, edited by Antonio Cassese (Oxford: Oxford University Press, 2012), p. xx. 
international criminal jurisdictions - sending 'real persons to real prisons' ${ }^{133}$ in Leila Nadya Sadat's jubilatory passage - that incarnate the most emblematic parts of today's international law. In contrast, societies at the highest stages of evolution in Saint-Simon's chronicle of human progress step-by-step no longer needed criminal law and the repressive administrations that go with it. Instead, energies were to be collectively directed towards the finality of ameliorating 'as promptly and as completely as possible the moral and physical existence of the most numerous class' ${ }^{134}$ the poor. Saint-Simon's religion of humanity focused on common moral ideas inspired by utilitarianism but with the strong social emphasis and concern which also inspired Marx and Engels. In his dream of future, progress at the age of maturity of human societies meant concrete well-being, spiritually and materially, not the possibility to condemn crimes or rights violations in order to express values for a better future.

Does anyone playing with the idea of international law as a 'religion of humanity' thus face the risk that a closer look reveals the famous opium in the valley of tears of human suffering, the illusion necessary to make the world seem to stand upright, although it is upside down? ${ }^{135}$ The apparent paradox is accentuated by unequal conditions of socio-economic, political, and military power and the firm grip 'civilized humanity' ${ }^{136}$ continues to hold on international law. One may dream of the ICC as an 'embodiment of ... a sovereigntyless conscience of humanity', ${ }^{137}$ yet its jurisdictional architecture rests on the presumption of protection of a sovereign state's might over its territory, nationals, and interests. Just as the ad hoc tribunals, the ICC was established only for situations where the state having jurisdiction is not respecting 'the duty of every State to exercise its criminal jurisdiction over those responsible for international crimes'. ${ }^{138}$ The reasons for the 'unwillingness or inability of the State genuinely to prosecute'139 can relate to a multitude of circumstances. The policy of 'positive complementarity' aims at 'developing national legal systems' of the weaker, typically post-colonial societies. ${ }^{140}$ The critique of this

133 Leila Nadya Sadat, The International Criminal Court and the Transformation of International Law: Justice for the New Millennium (Ardsley, N.Y.: Transnational Publishers, 2002), p. 8.

134 Saint-Simon, Nouveau Christianisme, p. 3185.

135 Karl Marx, Introduction to a Contribution to the Critique of Hegel's Philosophy of Rights, [18434], in Collected Works, vol. 3 (New York: Lawrence \& Wishart, 1979).

136 Martti Koskenniemi, From Apology to Utopia, p. 946. Compare to Arnulf Becker Lorca, 'Eurocentrism in the History of International Law', in The Oxford Handbook of the History of International Law, edited by Bardo Fassbender and Anne Peters (Oxford: Oxford University Press, 2012); Liliana Obregón, 'The Civilized and the Uncivilized', in The Oxford Handbook of the History of International Law (Oxford: Oxford University Press, 2012).

137 Bruce Rosenstock, 'Against Sovereign Impunity: The Political Theology of the International Criminal Court', in After Secular Law, edited by Winnifred Fallers Sullivan et al. (Stanford: Stanford Law Books, 2011).

138 Rome Statute of the International Criminal Court 91 July 2002), preamble.

139 Rome Statute, Article 17, see also Article 20.

140 The term is used by the Prosecutor's Office (http://www.icc-cpi.int/NR/rdonlyres/ 66A8DCDC-3650-4514-AA62-D229D1128F65/281506/OTPProsecutorialStrategy20092013.pdf), the Assembly of States Parties and NGOs. For analysis, see Benson Olugbuo, 'Positive Complementarity and the Fight Against Impunity in Africa', in Prosecuting International Crimes in Africa, edited by Chacha Murungu and Japhet Biegon (Pretoria: PULP, 2011); Hitomi Takemura, 'A Critical Analysis 
setting as 'neo-colonial' has valid points, while at the same time such claims are instrumentalized in national and international power struggles. ${ }^{141}$

Saint-Simon's narrative of the evolution of humanity has familiar features: the childlike barbaric early humans that need constraints to evolve into producers of economic well-being is reminiscent of how indigenous peoples were represented by international lawyers and politicians in times of conquests and colonialism. Past caricatures aside, how to explain that repression today is still considered more necessary in some societies, 'naturally' prone to conflict and violence? ${ }^{142} \mathrm{Or}$ that the understanding of violence as crime has a hierarchical ladder? How else to explain why technologically sophisticated violence-drone attacks being its most emblematic example today-does not feature in the focus of international criminal repression? Or large-scale economic, social, environmental crimes, part of which is 'slow violence', to use a term Rob Nixon coined in the context of the environment for 'violence that occurs gradually and out of sight, a violence of delayed destruction that is dispersed across time and space, an attritional violence that is typically not viewed as violence at all'143? A distinctively Durkheimian tone of sociological experiments with primitive societies- 'since the facts there are simpler, the relations between them are more apparent ${ }^{1144}$-lingers around the testing of dogmas of accountability, such as 'no peace without justice', ${ }^{145}$ that are not necessarily in use in the Global North.

The language and institutions of international criminal justice have in this manner taken a central place in the futurist, teleological, or eschatological streams of international law, right on the spot occupied some decades earlier by the development discourse that ran out of power. But focusing on individual criminal responsibility is not necessarily forwarding Saint-Simon's objective of creating a paradise of well-being and progress on Earth for people living right now, not in the future nor in heaven. In any case, the material or social benefits of international criminal

of Positive Complementarity', in Criminal Law between War and Peace, edited by Stefano Manacorda and Adán Nieto (Cuenca: Ed. de la Universidad de Castilla-La Mancha, 2009); Morten Bergsmo, Olympia Bekou, and Annika Jones, 'Complementarity After Kampala: Capacity Building and the ICC's Legal Tools', Goettingen Journal of International Law 2 (2010): pp. 791-811.

141 See, for example, Ifeonu Eberechi, 'Rounding Up the Usual Suspects: Exclusion, Selectivity, and Impunity in the Enforcement of International Criminal Justice and the African Union's Emerging Resistance', African Journal of Legal Studies 4, no. 1 (2011): p. 51; Nicholas Waddell and Phil Clark, eds, Courting Conflict? Justice, Peace and the ICC in Africa (London: Royal African Society, 2008); Dire Tladi, "The African Union and the International Criminal Court: The Battle for the Soul of International Law', South African Yearbook of International Law 34 (2009): p. 57. For a recent analysis of the discourse, see Anne-Charlotte Martineau, 'La justice pénale internationale, l'Afrique et le refoulé colonial', Champ pénal, vol. XIII (2016). https://champpenal.revues.org/9300.

142 For discussion on this, see Frédéric Mégret, 'Cour pénale internationale et néocolonialism: audelà des évidences', Études internationales 45, no. 1 (2014): pp. 27-50.

143 Rob Nixon, Slow Violence and the Environmentalism of the Poor (Cambridge, MA; London: Harvard University Press, 2011).

144 Durkheim, The Elementary, p. 7.

145 See, for example, Adam Branch, Keynote address delivered at 'The Politics of Peace and Justice' (Panel Discussion, International Criminal Court Review Conference, Kampala, Uganda, 3 June 2010). 
norms or procedures have yet to be documented, both in general and in the societies concerned. The experience of victims and victimized communities is particularly challenging to research, and the jury is still out on the pros and cons of retributive versus restitutive justice-which should in any case not be viewed as mutually exclusive. The ambitions of the ICC Trust Fund for Victims, for example, to use the meagre funds available towards 'transformative reparations' in the territories where ICC jurisdiction is exercised, 'with a view to eliminating the preexisting structural inequalities that have led to or encouraged the violence', ${ }^{146}$ remain isolated but telling rhetorical interventions symptomatic of the interventionist and omnipotent hubris of the international actors, at great distance from local ownership and agency, as well as democratic government. ${ }^{147}$

Saint-Simon's, Comte's, and Durkheim's ideas of progress were radically different from the progress aspired to by international law today. Ultimately, the difference culminates on what constitutes progress and who has access to the means to create progress. International criminal law and its institutions are arguably installed in the systemic conditions of capitalism, as part of a neo-liberal agenda. ${ }^{148}$ Saint-Simon's friendship of 'producers of all countries' 149 may have turned into today's 'transnational capitalist class' ${ }^{150}$ with a reduced agenda. In Saint-Simon's, Comte's, or Durkheim's visions for a better future, capitalism was not invariably malignant: the early phases of modern capitalism also symbolized human progress by commerce, industry, science, and technology. Durkheim, in particular, expected these changes to contribute to an organic division of work in societies bound together by social solidarity. My analysis has highlighted how this socio-liberal optimistic strain of heritage in international law today appears transformed into promises of progress by international norms-creation and institutional practice. Yet in the absence of global solidarity based on a consensual division of work, ${ }^{151}$ international law's current flagship-international criminal law and its institutional practice-may strike one as less related to palpable well-being in the countries or regions directly

146 Observations on Reparations in Response to the Scheduling Order of 14 March 2012, Lubanga (ICC-01/04-01/06-2872), Trials Chamber I, April 2012, \$77.

${ }_{147}$ For discussion, see Carolyn Hoyle and Leila Ullrich, 'New Court, New Justice?', Journal of International Criminal Justice 12 (2014): pp. 681-703. For a detailed analysis of the legal framework, see Conor McCarthy, Reparations and Victim Support in the International Criminal Court (Cambridge: Cambridge University Press, 2012).

148 See, for example, Grietje Baars, 'Making ICL History: On the need to move beyond pre-fab critiques of ICL', in Critical Approaches to International Criminal Law, edited by Christine Schwöbel, (Abingdon: Routledge, 2014); Tor Krever, 'International Criminal Law: an Ideology Critique', Leiden Journal of International Law 26 (2013): pp. 701-23. See also China Miéville, Between Equal Rights: A Marxist Theory of International Law (Netherlands: Brill, 2005); B.S. Chimni, 'International Institutions Today: An Imperial Global State in the Making', European Journal of International Law 15 (2004): pp. 1-37.

149 See Saint-Simon, Système industriel, III, p. 47, referred to by Durkheim, Socialism, p. 172.

150 See Robinson and Harris, 'Towards a Global Ruling Class? Globalization and the Transnational Capitalist Class', Science and Society 64 (2000): pp. 11-54.

${ }^{151}$ Applying Durkheim's Division of Labour to today's discourse on globalization, see Paul Hirsch, Peer C. Fiss, and Amanda Hoel-Green, 'A Durkheimian Approach to Globalization', in Oxford Handbook of Sociology and Organisational Studies, edited by Paul S. Adler (Oxford: Oxford University Press, 2008). 
concerned by the criminality it addresses than to desires for order and stability outside them. The evident problem is that the different 'stages of human development' are not gliding smoothly towards the future along the linear trajectories envisaged by evolutionary theorists and international law; they are concomitant, confronting each other in conflict, domination, subordination, or extermination. The same goes for the national and international sovereignties, their interests and their political, military, religious, or cultural agendas. Picturing these struggles and violence in the conditions of post-colonial instability and inequality as international crimes' subject to individual criminal responsibility, in accordance with criminological theories on attaining societal objectives by punishment-developed in the socio-economic conditions of the eighteenth-, nineteenth-, and twentiethcentury Christian societies in Western Europe ${ }^{152}$ and recently imported into the international politics as a powerful instrument to express shared values-requires a congregation of dogmas, mythologies, and credulity that would make many wellknown histories of miracles pale in comparison.

The foregoing suggestions flag the need for alternative frames of analysis of international law in order to redirect the focus from the eventual temptation of religiousness, old or new. The visions of Saint-Simon, Comte, and Durkheim were admirably ambitious in their orientation towards social, palpable justice, and solidary well-being. Yet Auguste Comte's deadline, the two centuries, has not been sufficient to create a moral community that is truly universal. Reading the UNDP Human Development Report 2014, there is no ambivalence on whether SaintSimon's twelfth phase of development of humanity has been reached. ${ }^{153}$ A dissolution of 'humanity' in the egoist materialism, Comte's 'grande hérésie', ${ }^{154}$ may strike one as a more adequate description. In contrast, the sweet scent of a powerful universal morality of 'humanity' currently imparted to international law, a secular surrogate religion, leans to the familiar European originalism in a hegemonic redescription of how international law and its institutions came about. A focus on religiousness as a discourse is a further choice of a point of view inwards, to 'our' beliefs and faith in setting up and dominating legal constructs and bureaucratic structures of institutional justice. With that move, the risk is that outward looking and critical research questions will remain in the margins. Who dares to inquire, for instance, how far international criminal law and its institutional practice today are one of the key mechanisms through which ideas about (political, social, cultural, racial) inferiority, subordination, or abject are constructed in international relations? Whereas international law can and also should be about justice, it is not carved in stone in the temples of 'humanity' nor whispered from behind the clouds by 'our' ancestors. Or else the risk is getting ruled out the politics of international

152 On the limits of criminology and on its Eurocentric or imperial tendencies, and on the possibilities of a renewal, see, for example, Biko Agozino, Counter-Colonial Criminology: A Critique of Imperialist Reason (London: Pluto, 2003); Wayne Morrison, Criminology, Civilisation and the New World Order (Abingdon: Routledge Cavendish, 2006).

153 http://hdr.undp.org/sites/default/files/hdr14-report-en-1.pdf.

154 Auguste Comte, Système de politique positive, I, p. 641. 
law that have social justice and solidarity as its objectives, including a broader and more just entitlement to economic welfare aspired by Saint-Simon, Comte, and Durkheim. Declining to address today's international law and its mediatized ceremonies of naming the crime and punishment as an incarnation of a fashionable retro faith has consequences for what is articulated and how, thereby becoming visible, open to critique, and change.

\section{Bibliography}

Abauzit, F. et al. 'Les Sentiments religieux à l'heure actuelle' (Paris: Vrin, 1919), translated and reprinted in Durkheim on Religion, J. Redding and W. S. F. Pickering, eds (London; Boston: Routledge and Kegan Paul, 1975), p. 187.

Agozino, Biko. Counter-Colonial Criminology: A Critique of Imperialist Reason (London: Pluto, 2003).

Alexander, Jeffrey C., and Philip Smith. 'Introduction: the new Durkheim'. In The Cambridge Companion to Durkheim, edited by Jeffrey C. Alexander and Philip Smith (Cambridge: Cambridge University Press, 2005).

Ansart, Pierre. Saint-Simon (Paris: PUF, 1969).

Arnaud, Pierre. La sociologie de Comte (Paris: PUF, 1969).

Aron, Raymond. La société industrielle et la guerre (Paris: Plon, 1959).

Aron, Raymond. Les étapes de la pensée sociologique (Paris: Gallimard, 1967).

Baars, Grietje. 'Making ICL History: On the Need to Move beyond Pre-fab Critiques of ICL'. In Critical Approaches to International Criminal Law, edited by Christine Schwöbel (Abingdon: Routledge, 2014).

Bandeira Galindo, George Rodrigo. 'Force Field: On History and Theory of International Law'. Rechtsgeschicte 20 (2012): pp. 86-103.

Bassiouni, M. Cherif, ed. The Statute of the International Criminal Court: A Documentary History (Ardsley, N.Y.: Transnational Publishers, Inc., 1998).

Beiner, Ronald. Civil Religion (New York: Cambridge University Press, 2011).

Bellah, Robert. 'Civil Religion in America'. Journal of the American Academy of Arts and Sciences 96, no. 1 (Winter, 1967): pp. 1-21.

Bergsmo, Morten, Olympia Bekou, and Annika Jones. 'Complementarity After Kampala: Capacity Building and the ICC's Legal Tools'. Goettingen Journal of International Law 2 (2010): pp. 791-811.

Berman, Nathaniel. 'In the Wake of Empire'. American University International Law Review 14 (1999): p. 1515.

Berman, Nathaniel. " "The Sacred Conspiracy": Religion, Nationalism, and the Crisis of Internationalism'. Leiden Journal of International Law 25, no. 1 (2012): pp. 9-54.

Bikundo, Edwin. International Criminal Law: Using or Abusing Legality? (Farnham: Ashgate, 2014).

Branch, Adam. 'The Politics of Peace and Justice' (Keynote address, Panel Discussion, International Criminal Court Review Conference, Kampala, Uganda, 3 June 2010).

Bucar, Elizabeth M., and Barbra Barnett, eds. Does Human Rights Need God? (Grand Rapids, Mich.: W. B. Eerdmans, 2005).

Cançado Trindade, Antônio Augusto. International Law for Humankind: Towards a New Jus Gentium (The Netherlands: Martinus Nijhoff Publishers, 2010).

Cassese, Antonio. 'Introduction'. In Realizing Utopia: The Future of International Law, edited by Antonio Cassese (Oxford: Oxford University Press, 2012), p. xx. 
Chimni, B. S. 'International Institutions Today: An Imperial Global State in the Making'. European Journal of International Law 15 (2004): pp. 1-37.

Clarke, Kamari M. Fictions of Justice (Cambridge; New York: Cambridge University Press, 2009).

Comte, Auguste. Troisieme opuscule: Considérations philosophiques sur les sciences et les savants (1825). http://classiques.uqac.ca/classiques/Comte_auguste/la_science_sociale_extraits/ 1_opuscules_philo_soc/opuscules_philo_sociale.pdf (last visited 8 June 2015).

Comte, Auguste. Système de politique positive ou traité de sociologie instituant la religion de l'Humanité, vols I-II (Paris: Libraire positiviste, Georges Crès et Cie, 1851-54).

Comte, Auguste. Système de politique positive ou traité de sociologie instituant la religion de l'Humanité, vol. IV, edited by Mathias, Carilian-Goeury and V. Dalmont, 5th edn (Paris: Siege de la Société Positiviste, 1929 [1851-54]).

Comte, Auguste. Cours de philosophie positive, Euvres VI (Paris: Les Editions Anthropos, 1968).

Comte, Auguste. Philosophie des sciences, edited by Juliette Grange (Paris: Gallimard, 1996).

Comte, Auguste. Discours sur l'ensemble du positivisme [1848] (Paris: Flammarion, 1998).

de Condorcet, Nicolas. Esquisse d'un tableau historique des progrès de l'eprit humain (179495). Bibliothèque de Philosophie (Paris: Boivin, 1933).

Cotterell, Roger. Emile Durkheim: Law in a Moral Domain (Edinburgh: Edinburgh University Press, 1999).

Cotterell, Roger. 'The Concept of Crime and Transnational Networks of Community'. In Globalisation, Criminal Law and Criminal Justice, edited by V. Mitsilegas, P. Alldridge, and L. Cheliotis (Oxford: Hart, 2015).

Durkheim, Emile. 'Deploige, Simon, Le conflit de la morale et de la sociologie'. L'Année sociologique XII (1913): pp. 326-8.

Durkheim, Emile. Socialism and Saint-Simon (Ohio: The Antioch Press, 1958).

Durkheim, Emile. Moral Education (New York: The Free Press of Glencoe, 1961).

Durkheim, Emile. The Elementary Forms of the Religious Life, 7th edn (London: Allen \& Unwin, 1971).

Durkheim, Emile. 'Two Laws on Penal Evolution'. Economy and Society 2, no. 3 (August 1973): pp. 285-308.

Durkheim, Emile. 'L'Individualisme et les intellectuels'. In Revue Bleue 4e série, X (1898), pp. 7-13, 10; translated by S. Lukes and J. Lukes, Political Studies, XVII (1969), pp. 1930, reprinted in W. S. F. Pickering, Durkheim on Religion (London; Boston: Routledge $\&$ K. Paul, 1975).

Durkheim, Emile. The Division of Labour in Society (New York: Macmillan, 1984, re-edited New York: The Free Press, 1997).

Eberechi, Ifeonu. 'Rounding Up the Usual Suspects: Exclusion, Selectivity, and Impunity in the Enforcement of International Criminal Justice and the African Union's Emerging Resistance'. African Journal of Legal Studies 4, no. 1 (2011): p. 51.

Feichtner, Isabel. 'Realizing Utopia through the Practice of International Law'. European Journal of International Law 23 (2012): pp. 1143, 1154.

Fournier, M. Emile Durkheim 1858-1917 (Paris: Fayard, 2007).

Geertz, Clifford. 'Centers, Kings and Charisma: Reflections on the Symbolics of Power'. In Local Knowledge: Further Essays in Interpretative Anthropology (New York: Basic Books, 1983).

Gouhier, Henri. La vie d'Auguste Comte (Paris: Gallimard, 1931).

Gouldner, Albin W. 'Introduction'. In Emile Durkheim, Socialism and Saint-Simon (Ohio: The Antioch Press, 1958). 
Grange, Juliette. La philosophie d'Auguste Comte: science, politique, religion (Paris: PUF, 1996). Grange, Juliette. Saint-Simon (1760-1825) (Paris: Ellipses, 2005).

Grewe, Wilhelm G. The Epochs of International Law (Berlin; New York: Walter de Gruyter, 2000).

Hammill, Graham, and Julia Reinhard Lupton. 'Introduction'. In Political Theology and Early Modernity, edited by Graham Hammill and Julia Reinhard Lupton (Chicago; London: The University of Chicago Press, 2012), pp. 1-7.

Haskell, John. 'Divine Immanence: The Evangelical Foundations of Modern AngloAmerican Approaches to International Law'. Chinese Journal of International Law 11, no. 3 (2012): pp. 429-67.

Hirsch, Paul, Peer C. Fiss, and Amanda Hoel-Green. 'A Durkheimian Approach to Globalization'. In Oxford Handbook of Sociology and Organisational Studies, edited by Paul S. Adler (Oxford: Oxford University Press, 2008).

Hoyle, Carolyn, and Leila Ullrich. 'New Court, New Justice?'. Journal of International Criminal Justice 12 (2014): pp. 681-703.

Human Development Report 2014. Available at: http://hdr.undp.org/sites/default/files/ hdr14-report-en-1.pdf.

Huvelin, Paul. 'Magie et droit individuel'. L’Année sociologique (1905-06).

Ignatieff, Michael. Human Rights as Politics and Idolatry (Princeton: Princeton University Press, 2003).

Keenan, Joseph B., and Brendan F. Brown. Crimes Against International Law (Washington, Public Affairs Press, 1950).

Kennedy, David. 'Losing Faith in the Secular: Law, Religion, and the Culture of International Governance'. In Religion and International Law, edited by Mark Janis and Carolyn Evans (The Hague; Boston: Martinus Nijhoff Publishers, 1999), pp. 309-20.

Kertzer, David. Ritual, Politics, and Power (New Haven; London: Yale University Press, 1988).

Koskenniemi, Martti. The Gentle Civilizer of Nations: The Rise and Fall of International Law 1870-1960 (Cambridge: Cambridge University Press, 2002).

Kreß, Claus. 'Towards a Truly Universal Invisible College of International Criminal Lawyers'. FICHL Occasional Paper Series No. 4 (2014). https://www.legal-tools.org/doc/ 82bf10/ (last visited 15 April 2015).

Krever, Tor. 'International Criminal Law: An Ideology Critique'. Leiden Journal of International Law 26 (2013): pp. 701-23.

Laval, Christian. L'ambition sociologique (Paris: Editions La Decouverte \& Syros, 2002).

Lettres inédites de John Stuart Mill à Auguste Comte (Paris: Alcan, 1899).

Lorca, Arnulf Becker. 'Eurocentrism in the History of International Law'. In The Oxford Handbook of the History of International Law, edited by Bardo Fassbender and Anne Peters (Oxford: Oxford University Press, 2012).

Luban, David. 'After the Honeymoon'. Journal of International Criminal Justice 11 (2013): pp. 505-15.

Lukes, Steven. Emile Durkheim: His Life and Work-a Historical and Critical Study (London: Allen Lane the Penguin Press; Stanford, CA: Stanford University Press, 1973). Lukes, Steven, and Andrew Scull. 'Introduction'. In Durkheim and the Law, edited by Steven Lukes and Andrew Scull (Great Britain: Billing and Sons Ltd, 1983).

Löwith, Karl. Meaning of History (Chicago; London: The University of Chicago Press, 1949). Marks, Susan. 'Human Rights in Disastrous Times'. In The Cambridge Companion to International Law, edited by James Crawford and Martti Koskenniemi (Cambridge: Cambridge University Press, 2012), pp. 309-26, 313-14. 
Martineau, Anne-Charlotte. 'La justice pénale internationale, l'Afrique et le refoulé colonial'. Champ pénal, vol. XIII (2016). https://champpenal.revues.org/9300

Marx, Karl. The Capital, Volume III. pp. 431-34. https://www.marxists.org/archive/marx/ works/download/pdf/Capital-Volume-III.pdf.

Marx, Karl, and Friedrich Engels. Utopisme et communauté de l'avenir (Paris: François Maspero, 1976).

Marx, Karl. 'Introduction to a Contribution to the Critique of Hegel's Philosophy of Rights, [1843-44]'. In Collected Works, vol. 3 (New York: Lawrence \& Wishart, 1979).

Mauss, Marcel. La religion et les origines du droit pénal d'après un livre récent. Oeuvres, 2. Representations collectives et diversité des civilisations (Paris: Les editions de minuit, 1968).

McCarthy, Conor. Reparations and Victim Support in the International Criminal Court (Cambridge: Cambridge University Press, 2012).

Mégret, Frédéric. 'Cour pénale internationale et néocolonialism: au-delà des évidences'. Etudes internationales 45, no. 1 (2014): pp. 27-50.

Mégret, Frédéric. 'International Criminal Justice: A Critical Research Agenda'. In Critical Approaches to International Criminal Law, edited by Christine Schwöbel (Abingdon: Routledge, 2014), pp. 17, 43.

Miéville, China. Between Equal Rights: A Marxist Theory of International Law (Netherlands: Brill, 2005).

Mill, John Stuart. Auguste Comte and Positivism (London: Trübner, 1866).

Mill, John Stuart. The Utility of Religion. In Three Essays on Religion (Amherst: Prometheus, 1998 [1874]).

Mitchell, Audra. International Intervention in a Secular Age: Re-enchanting Humanity? (London: Routledge, 2014).

Morrison, Wayne. Criminology, Civilisation and the New World Order (Abingdon: Routledge Cavendish, 2006).

Moyn, Samuel. Human Rights and the Uses of History (London; Brooklyn, N.Y.: Verso, 2014).

Musso, Pierre. Saint-Simon et Saint-Simonisme (Paris: PUF, 1999).

Nancy, Jean-Luc. 'Church, State, Resistance'. In Political Theologies, edited by Hent de Vries and Lawrence E. Sullivan (New York: Fordham University Press, 2006).

Nimage, Salif. 'An International Conscience Collective?'. International Criminal Law Review 7 (2007): pp. 561-619.

Nixon, Rob. Slow Violence and the Environmentalism of the Poor (Cambridge, Mass.; London: Harvard University Press, 2011).

Obregón, Liliana. 'The Civilized and the Uncivilized'. In The Oxford Handbook of the History of International Law (Oxford: Oxford University Press, 2012).

Observations on Reparations in Response to the Scheduling Order of 14 March 2012, Lubanga (ICC-01/04-01/06-2872), Trials Chamber I, April 2012, $\$ 77$.

Olugbuo, Benson. 'Positive Complementarity and the Fight Against Impunity in Africa'. In Prosecuting International Crimes in Africa, edited by Chacha Murungu and Japhet Biegon (Pretoria: PULP, 2011).

Phillips, Elisabeth. Political Theology—A Guide for the Perplexed (London; New York: T\&T Clark, 2012).

Pickering, Mary. Auguste Comte: An Intellectual Biography, vols 1-3 (Cambridge: New York: Cambridge University Press, 1993, 2009).

Pickering, W. S. F. Durkheim's Sociology of Religion (Cambridge: James Clarke \& Co, 2009).

Porsdam, Helle, ed. Civil Religion, Human Rights and International Relations (Cheltenham: Edward Elgar, 2012). 
Robbins, Bruce. Feeling Global: Internationalism in Distress (New York; London: New York University Press, 1999).

Robinson, William I. and Jerry Harris. 'Towards a Global Ruling Class? Globalization and the Transnational Capitalist Class'. Science and Society 64 (2000): pp. 11-54.

Rosenstock, Bruce. 'Against Sovereign Impunity: The Political Theology of the International Criminal Court'. In After Secular Law, edited by Winnifred Fallers Sullivan et al. (Stanford: Stanford Law Books, 2011).

Rousseau, Jean-Jacques. Du contrat social (Paris: Garnier-Flammarion, 1966 [1762]).

Sadat, Leila Nadya. The International Criminal Court and the Transformation of International Law: Justice for the New Millennium (Ardsley, N.Y.: Transnational Publishers, 2002).

Saint-Simon, Henri. Oeuvres complètes, vols I-IV, edited by Juliette Grange, Pierre Musso, Philippe Régnier, and Frank Yonnet (Paris: PUF, 2012).

van Schaak, Beth. 'Crimen sine lege: Judicial Lawmaking at the Intersection of Law and Morals'. Georgetown Law Journal 97 (2008-09): p. 157.

Shils, Edward. The Constitution of Society (Chicago: University of Chicago Press, 1982).

Skouteris, Thomas. The Notion of Progress in International Law Discourse (The Hague: T.M.C. Asser Press, 2010).

Smith, Robertson. Lectures on the Religion of the Semites (Edinburgh: 1889; 3rd edn London: 1927).

Statement by H.E. Ambassador Markus Börlin, Vice-President of the Assembly of States Parties, 16 April 2013. Available at: http://www.icccpi.int/en_menus/icc/press $\% 20$ and\%20media/press\%20releases/Documents/pr898/Groundbreaking-Ceremony-ASPVice-President-Statement.pdf (last consulted 14 April 2015).

Takemura, Hitomi. 'A Critical Analysis of Positive Complementarity'. In Criminal Law between War and Peace, edited by Stefano Manacorda and Adán Nieto (Cuenca: Ed. de la Universidad de Castilla-La Mancha, 2009).

Tallgren, Immi. 'The Sensibility and Sense of International Criminal Law'. European Journal of International Law 13, no. 3 (2002): pp. 561-95.

Tallgren, Immi. 'The Durkheimian Spell of International Criminal Law?'. In Revue interdisciplinaire d'études juridiques 71 (2013): pp. 157-189.

Tarot, Camille. De Durkheim à Mauss, l'invention du symbolique (Paris: Editions la Découverte/M.A.U.S.S., 1999).

Taylor, Keith. The Political Ideas of the Utopian Socialists (Great Britain: Frank Cass and Company Limited, 1982).

Teitel, Ruti G. Humanity's Law (Oxford: Oxford University Press, 2011).

Tladi, Dire. 'The African Union and the International Criminal Court: The Battle for the Soul of International Law'. South African Yearbook of International Law 34 (2009): p. 57.

de Vries, Hent. 'Introduction'. In Political Theologies, edited by Hent de Vries and Lawrence E. Sullivan (New York: Fordham University Press, 2006), pp. 25-7.

Waddell, Nicholas and Phil Clark, eds. Courting Conflict? Justice, Peace and the ICC in Africa (London: Royal African society, 2008).

Weber, Max. Theory of Social and Economic Organization (New York: Free Press, 1947).

Wernick, Andrew. Auguste Comte and the Religion of Humanity: The Post-theistic Program of French Social Theory (Cambridge; New York: Cambridge University Press, 2001).

Wiesel, Elie. 'A Tribute to Human Rights'. In The Universal Declaration of Human Rights: Fifty Years and Beyond, edited by Danieli Yael et al. (Amityville, N.Y.: Baywood, 2009), p. 3.

Wilson, Richard Ashby, and Richard D. Brown, eds. Humanitarianism and Suffering (New York: Cambridge University Press, 2009). 